NK

3049

B3B85

1889

CHM
Philadklphia museum of art The Bayeux tapestry 



\section{The dentins}

TIIE PENNSYLNANIA MUSEUM

AND

SCHOOL OF INDUSTRIAL ART.

\section{A BRIEF HISTORY}

\section{BAYEUX TAPESTRY,}

WITH A

\section{DESCRIPTION OF THE SCENES.}

Compiled from the work entitled The Bayeux Tapestry, by Frank Rede Fowke, and the Notice sur la Tapisserie dite de la Reine Mathilde, by l'abbe J. Laffetay. 



\section{THE PENNSILVANIA MUSEUM}

$\mathrm{AND}$

SCHOOL OF INDUSTRIAL ART.

\section{A BRIEF HISTORY}

ul

OF THE

\section{BAYEUX TAPESTRY,}

WITH A

\section{DESCRIPTION OF THE SCENES.}

Compiled from the work entitled The Bayeux Tapestry, by Frank Rede Fowke, and the Notice sur la Tapisserie dite de la Reine Mathilde, by l'abbé J. Laffetay.

MEMORIAL HALL, Fairiodn Park, Philadelphia, 1889. 
The copy of the Tapestry in the Pennsylvania Museum is an exact $\int a c$ simile in the minutest details of the original work, made by an autotype process and colored by hand. Certain grossnesses in the borders have been erased. 


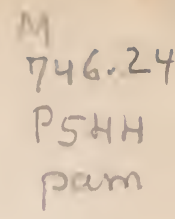

\section{THE BAYEUX TAPESTRY.}

THE Bayeux Tapestry is a band of linen two hundred and thirty feet long by twenty inches wide, containing a series of pictures illustrating the Norman Conquest of England and justifying from a Norman standpoint the claim of William the Conqueror to the English throne. The work is really a kind of embroidery, being done with a needle in worsteds of eight different colors, but as it has been known and described so long as the Bayeux Tapestry that name will probably never be changed.

The earliest mention of the tapestry is found in the inventory of the ornaments in the Cathedral of Bayeux, taken in 1476 . It was used in the decoration of that church during the Feasts of the Relics and of the Dedication, and when hung up it measured exactly the length of the walls of the nave round which it was placed. Here it remained obscure and neglected for two hundred and fifty years, until in I724, being brought by a fortunate accident to the attention of the French Academy of Inscriptions, its extraordinary historical value was speedily recognized, and steps were at once taken to save it from being subjected to further wear and tear. It is now kept framed and glazed in a building especially erected for its exhibition, where it is guarded with jealous care by the municipal authorities as one of the most precious possessions of the town.

Once only, when at the command of Napoleon it was exhibited for a short time in Paris, has the tapestry been removed from Bayeux. If Mr. Fowke's conjecture as to its origin is correct, it was probably placed in the cathedral of that town within a few years of the Conquest. When we consider the rude and disturbed condition of Europe in those days and during the centuries that followed, the preservation of this long roll of embroidered linen to our times seems little short of miraculous.

By whom the tapestry was made, whether by English or Norman workmen, has been the subject of a great deal of conjecture. Some think that it is the handiwork of the Queen Matilda, who was the wife of the Conqueror. Others think that it was made by English workmen for the Empress Matilda, his grand-daughter, who in this way commemorated the achievements of her great ancestor. Mr. Fowke's opinion is that the tapestry is Norman workmanship, done at the order of Bishop Odo for the decoration of his Cathedral of Bayeux, which he rebuilt in 1077. Accepting this latter view as the correct one, the tapestry may be regarded as a contemporary Norman chronicle of the 
events of the Conquest. These events are shown in a series of seventytwo compartments or scenes, which are generally separated from each other by conventionally rendered trees or buildings. The intention of most of the compartments is explained by Latin inscriptions placed over them. The letters, like the figures, are stitched in worsted. While the composition of the groups is bold and spirited, the drawing of the figures is for the most part rude and uncouth, nor has any great attention been paid to the representation of objects in their natural colors. Thus horses are shown as blue, green, red, and yellow, a circumstance no doubt due to the limited number of colors at the artist's disposal. Working with flat tints the embroiderers had no means of giving effects of light and shade, and perspective is almost wholly disregarded. To indicate therefore objects at different distances from the spectator they employed worsteds of different colors. Thus a green horse has his off legs red, those of a yellow horse are blue, and so on.

The mode of working has been to cover the figures with worsted threads laid down flat, side by side, and then bound at intervals by cross fastenings ; seams, joints, and folds being indicated by a species of twist. The faces and hands of persons are simply stitched in outline in colored worsteds.

The really historical part of the tapestry is confined to the middle portion, the top and bottom forming fantastic borders, containing lions, birds, dragons, \&c., some fables of Esop and Phædrus, and scenes of husbandry and the chase. Towards the end the border is taken into the thread of the story, and it frequently contains allegorical allusion to the scenes being enacted in the story itself.

Apart from the historical narrative the tapestry furnishes abundant material for studying the architecture, the arms and armor, the costumes, and the manners and customs of the period of the Conquest. The beginnings of heraldry may be seen, too, in the blazons on the shields of the knights.

The story is told in the adventures of one Harold, a powerful English earl, who was brother-in-law to King Eadward the Confessor. Harold was sent by King Eadward to Normandy to assure Duke William of his succession to the crown. While on the way he landed on the coast of Ponthieu, and was taken prisoner by a certain Count Guy, the lord of that region. As was the custom in those days, Guy held Harold for a heavy ransom. When Duke William heard of the capture of Harold, he ordered his release, and had him brought to his capital of Rouen. While here Harold accompanied William on a raid into Brittany. Now, while it is doubtful whether Harold delivered his message, or whether William had or had not previously received a promise from King Eadward relative to the succession, it is certain that at this time William did, for some reason or other, publicly aspire to become the King of England. Perhaps it was because he now had Harold in his power. Therefore, knowing that Harold would be a powerful rival if the claim should be disputed, he called a great assemblage of nobles together, and announced to them that at 
Eadward's death he meant to claim the crown. Then IVilliam required Harold to take a solemn oath before the assemblage to assist him in his purpose. The oath taken, Harold was allowed to return to England. Within a week Eadward died, and on the very day that he was buried Harold had himself crowned King of England by the English Archbishop Stigand.

When IVilliam heard what Harold had done, he prepared to invade England and punish Harold for his perfidy. The way Harold had been crowned aided IVilliam's cause. Stigand was an archbishop whom the English had nominated, and whom the usurping Pope Boniface had acknowledged, but whom Pope Alexander had repudiated. Therefore, when Villiam proclaimed his purpose, Pope Alexander blessed the enterprise and sent IVilliam a consecrated banner, round which the barons of France leagued themselves together. Harold's rebel brother Tostig, and the King of Norway, also joined their forces against the English king. Harold was waiting for IVilliam at Hastings, on the south coast. When he heard that his brother Tostig had landed up in the north, and was besieging York, Harold immediately marched to the relief of that town, and defeated and slew Tostig in the battle of Stamford Bridge. Three days later the Normans landed at Pevensey, near Hastings, and Harold had to hasten south again. The tapestry now ends with the death of Harold and the flight of the English after the battle of Hastings. It may be conjectured with probability, however, that the obliterated portion completed the story by representing the pursuit of the Normans, and the proclamation of William as King.

The bibliography of the tapestry would by itself fill a small volume. Many works have been written on the vexed question of its origin and authorship, and of the true significance of the pictorial chronicle. Numerous special treatises descant upon the lessons to be learned from the heraldry, the arms and armor, the costumes and the types of architecture that are figured in the embroidery. The foremost English study of the work is that made by Mr. Frank Rede Fowke in his book entitled The Bayeux Tapestry. The student may also consult Freeman's History of the Noman Conquest; The Bayeux Tapestry, by Rev. J. C. Bruce ; Textile Fabrics, by Very Rev. D. Rock; Les Arts au Moyen Age, by Paul Lacroix; Notıce Historique sur la Tapisserie, by l'abbé J. Laffetay. 


\section{THE BAYEUX TAPESTRY.}

\section{EDWARD REX :}

King Eadward.

King Eadward the Confessor is seated on a cushioned throne in a vaulted apartment of his royal palace of Westminster.

The exterior of the palace shows that it was a building of considerable architectural pretension. The face of the tower is covered with checkered work, of which examples still exist in Normandy. The entrance is through a gateway under a plain semicircular arch.

Eadward's crown is a simple circlet ornamented with fleurs-de-lys. A similar decoration terminates the sceptre held in his left hand. With his right hand Eadward emphasizes the remarks he is addressing to two persons of rank standing before him. The taller of them is Harold, son of Earl Godwine, and brother-in-law to the King.

Two interpretations are given of this opening scene: One, that Harold is seen here asking permission to cross the sea and reclaim the members of his family whom King Eadward has placed with Duke William for safe-keeping as hostages for Earl Godwine's good behavior. The other, that it represents King Eadward commissioning Harold to proceed to Normandy to assure Duke William of his nomination as Eadward's successor to the English throne. Either view may be correct, but the latter is more in accord with the general plan of the tapestry, which is designed to strengthen the Norman claim and to emphasize the perfidy of Harold.

VBI: HAROLD DVX: ANGLORVM : ET SVI MILITES: EQVITANT: AD BOSHAM :

Where Harold, a chief of the English, and his knights, ride to Bosham.

Bosham was a manor on the south coast of England, opposite Picardy, that Harold had received from his father. $\mathrm{He}$ goes 
thither to prepare for his departure into Normandy. In those days great men spent most of their time either in hunting or fighting. When not wearing their war-harness they were following the chase. Hawking, long practiced by the Normans, had already become a favorite pastime with the Anglo-Saxons. Harold as he rides to Bosham amuses himself with his hawk and hounds. Observe that Harold wears a mantle or cloak fastened at the right shoulder with a clasp. This garment was worn only by persons of distinction. At the time of the Conquest the dress of the AngloSaxons and of the Normans was pretty much the same. The bodycovering of men was a tunic, open in front, and put on over the head like a shirt. It was girded at the waist by a belt. The length of the tunic indicated the rank of the wearer. With the common people it reached only to the knee. Super-tunics, and the cloak or mantle mentioned above, were worn only by people of distinction or gentle birth. For leg-covering the common people wore short hose, and the nobles long stockings, often reaching to the thigh. Breeches and trousers were coming into use, but were not yet common. Shoes or buskins were generally worn. Among the Normans there was a custom of ornamenting the shoes with little leather straps reaching to the knee, the legs being wound with bands of various colors. This method of cross-gartering is frequently shown in the tapestry.

Another fashion that may be noticed here was the manner of wearing the hair and beard. The Norman custom was to have the head tonsured and the face clean-shaven. The Saxons did not shave the head and commonly wore moustaches. This distinction is generally, although not always, made by the designer of the tapestry. It often assists us in interpreting the story. Among the Saxons, King Eadward alone is represented with a chin beard. Among the Normans, Turold the dwarf, two ship-carpenters, a sailor, and a guest at Bishop Odo's table all have chin beards.

At the period represented the equipments of the horses were pretty much the same as those of the present time. The saddles are high-peaked and apparently made of wood. Stirrups are generally, but not always, used.

\section{ECCLESIA :}

\section{The Church.}

After his arrival at Bosham Harold first goes to the church to seek a blessing on his enterprise. He enters the sacred edifice 
with reverent genuflexions. It is interesting to notice how many architectural details are shown in this rude drawing; the approach by a flight of steps; the simple nave lighted by a clerestory; the buttressed walls; the arched entrance; the rounded shingles or tiles nailed to the framework of the roof; and the crosses at either end.

His devotions finished, Harold returns to his manor-house to pass the time in feasting and carousal while the ship is making ready. The manor is built like an ancient peal-house, vaulted below and divided into aisles. The feast is spread in a large solar or upper hall, reached by a flight of stairs from without. Harold and his companions are seen pledging each other in bowls and horns of wine.

HIC HAROLD $\because$ MARE NAVIGAVIT $\because$ ET VELIS : VENTO : PLENIS VENIT: IN TERRA: WIDONIS COMITIS

Here Harold set sail upon the sea, and with sails filled by the wind came to the land of Count Guy.

A messenger announces that the preparations for the voyage are complete. Harold and his companions wade out to the boat that is to take them aboard the ship, carrying their hounds and hawk with them. This boat is fitted with thwarts for rowers, and is shown again in the scene on the French coast. Harold's warship also is shown twice-once on leaving England and again on approaching the land of Ponthieu (Picardy) of which Guy was count.

As we shall see later, the English and the Norman ships were very much alike. The body is made gay with bright-colored paints, the bow and stern parts are surmounted by carved and gilded figure-heads. The single mast is traversed by a yard on which the square and party-colored sail is set. The low sides of the vessel are made higher while sailing, by interlocking the shields of the soldiers above the bulwarks. Below are holes for thrusting out oars for rowing. A paddle is used for steering the ship.

In the first scene are shown the preparations making for getting under way. Harold has taken the steering paddle and is directing the setting of the sail. In the second scene we have depicted the approach to shore; the watch at the masthead; men shortening sail; others poling the vessel; and a man standing ready to cast the anchor. 


\section{HAROLD $\because$}

Harold.

There is a tradition that Harold's ship was driven by stress of weather upon the coast of Ponthieu. There is no indication of a storm in the last scene, although Harold's landing is evidently without warlike intention, as he would not have landed clad only in his mantle and without other armor than a spear, had his purpose been hostile. Again, the seizure of the party by Count Guy accords with the custom of the day of making prisoners of all strangers cast by a tempest upon the coast and holding them for ransom.

\section{HIC : APPREHENDIT : WIDO : HAROLDV : Here Guy scized Harold.}

Harold and his attendants, after a brief struggle, are made prisoners by Count Guy and his party. The latter are well armed and mounted on powerful Norman steeds. The difference in size between the horses of Normandy and of England is noticeable in the tapestry. The shields carried by the men of Guy are covered with strange devices, in which some antiquarians see the rudiments of the heraldic blazon which is found in the time of the Crusades.

\section{ET DVXIT: EVM AD BELREM: ET IBI EVM: TENVIT :}

\section{And led him to Beaurain and there imprisoned him.}

The capture effected, Guy's party turns about and proceeds to Guy's chateau of Beaurain. Harold's companions walk first in the custody of two of the Count's soldiers. There is some doubt as to which of the two mounted figures, each with a hawk upon his fist, is intended to represent Harold. The foremost figure is usually taken to be Guy, but more probably represents Harold. He has a moustache and wears a cloak, like Harold in the landing scene. $\mathrm{He}$ is also unarmed, while the second figure is armed and spurred, is clean shaven and without a cloak, in all of which points he corresponds with the previous portrait of Guy.

\section{VBI : HAROLD : T WIDO: PARABOLANT :}

Where Harold and Guy converse.

Harold is given audience in a vaulted apartment of the chateau. The ceiling is carried on slender shafts curiously foliated in the 
middle and terminating in a heavy capital. His sword has been restored to him and he is accompanied by an attendant. Guy is seated upon a throne and holds a sword of justice in his hand. An attendant endeavors to call his attention to something passing without-possibly the approach of the messengers whom we shall see in the next picture. From the antic dress and attitude of the man by the column, he has been conjectured to be the Count's jester; but where so much is guess-work, we may venture the suggestion that this man represents the woodsman whom we shall see three scenes farther on.

\section{VBI : NVNTII : WILLELMI : DVCIS : VENERVNT : AD WIDONE}

\section{Where Duke William's messengers came to Guy.}

In this section and in the two following sections, the order of time is reversed. In this section we see the arrival of two messengers sent by Duke William to demand Harold's release. In the next we shall see them on the road, and in the third we find them starting on their errand.

Guy receives the messengers in an unfriendly manner. He holds his battle-axe in his hand and has his war-harness on under his cloak. His attendant appears to be threatening the messengers. We shall see, however, that he was finally persuaded to yield to the Duke's demand.

In the lower margin of this section is a most interesting agricultural scene. One man is ploughing the land, another harrowing the furrows, and a third sowing seed. A youth is driving away the birds with a sling. It is noteworthy to observe that we do not find the use of the sling depicted in any of the scenes of combat, so that presumably it was only used as a weapon of the chase.

\section{TVROLD. \\ Turold.}

Under this name we see a dwarf, who is holding the messengers' horses. This little figure has been commonly supposed to represent the designer of the tapestry, who has taken this method of introducing himself and his name into the work. Mr. Fowke, however, is of the opinion that Turold is the name of one of the messengers, and that the name has been inclosed between the two lines attaching 
it to the back of the person indicated, that there may be no mistake as to his identity.

Whoever the dwarf may be, there is no mistaking his nationality because, although he wears a beard, his head is shaven in the Norman fashion.

\section{NVNTII : IVILLELMI \\ William's Messengers.}

The messengers are galloping toward Beaurain, which is shown here in a view of the exterior. The watchman in the tree is commonly said to be one of Duke William's men, who looks after the messengers until they are out of sight. We have ventured the suggestion that this is the man in the third scene back, who is commonly taken to be the Count's jester. He is one of Count Guy's men, perhaps a woodsman, who discovers the approach of the messengers and hastens by some short path to apprise his master of their coming. In the former scene we see this man ushered into the presence of Count Guy by an attendant, who interrupts the Count to tell him what important news the woodsman brings.

\section{+ HIC VENIT: NVNTIVS: AD WILGELMVM DVCEM}

\section{Here the messenger came to Duke William.}

William was at his castle of Rouen when the Englishman who apprised him of Harold's capture arrived. The man presents himself as a suppliant, and is kindly received by the Duke. The latter immediately dispatches the two knights accompanying the messenger to demand Harold's ransom. William is seated on a throne very similar to the throne of Guy. His castle of Rouen is represented as a strong, square fortress, the ramparts flanked with towers dominated by a massive keep. The ashlar work is very distinctly shown in this building.

\section{HIC: WIDO: ADDVXIT HAROLDVM AD WIL- GELMVM : NORMANNORVM : DVCEM \\ Here Guy conducted Harold to William, Duke of the Normans.}

We see here the result of William's demand. The Count of Ponthieu himself delivers Harold to the Duke. Both parties are accompanied by armed escorts. Harold has had his spurs returned 
to him and he wears, in common with Guy and William, the mantle of noble birth. The figure of William is drawn with unusual care, and it becomes peculiarly interesting when we reflect that this picture may be no fancy portrait, that the designer of the tapestry may have looked upon the Conqueror and drawn this design from life.

\section{HIC: DVX:-WILGELM : CVM HAROLDO : VENIT: AD PALATIV SVV}

\section{Here Duke William, together with Harold, came to his palace.}

A watchman on a tower is on the lookout for the approach of the party. The building represented is supposed to be William's palace at Rouen. After their arrival William receives Harold in a vast apartment, the roof of which appears to be supported on arches, somewhat like a clerestory. We are now approaching the most puzzling portion of the tapestry. What was the nature of the interview between Harold and William, and did it have any connection with the scene next following? Some commentators find no connection between the scenes, and assert that here we have Harold delivering his message from King Eadward or praying William to send messengers to England with news of his rescue. Other commentators connect the scenes by interpreting this one as showing Harold promising to marry William's daughter, and the next one as showing a clerk receiving the promise of acceptance from the princess, and giving her a cuff on the cheek that she may not forget her troth. The above and many other conjectures regarding the meaning of these scenes have been made-no one of which, however, is altogether satisfactory. Mr. Fowke connects the scenes by still another reading, which, as it has several elements of probability, is the one that we shall adopt. This reading is given with the next scene.

\section{VBI : VNVS: CLERICVS: ET: ÆLLFG广்A Where a certain Clerk and Alfgyva...}

The inscription here, either by design or accident, is incomplete. Elfgyva is the name of a Saxon lady, perhaps of Harold's sister, who accompanied Wulfnoth when he was sent by Eadward into Normandy. At any rate, Elfgyva is some one in whom Harold is interested. In his interview with William, Harold announces to the Duke that he has learned that $\mathbb{E l f g y v a}$ is at Dol一a town on the 
borders of Brittany-and that violence has been offered to her. $\mathrm{He}$ begs William's aid to rescue her. William, who is about making an expedition against Conan, Count of Brittany, readily acquiesces. In this picture of $Æ$ lfgyva being carried off from the door of her residence, we are shown the cause of Harold's solicitude. The next scene shows the departure of the expedition.

\section{HIC - IVILLEM : DVX: ET EXERCITVS: EIVS: VENERVNT: AD MONTE MICHAELIS}

Here Duke William and his army came to Mont Saint-Michel.

The route of the expedition is indicated by a view of Mont Saint-Michel. The abbé Laffetay directs attention to the different styles of military dress depicted here. He states that those wearing coats of mail and helmets with the nose-piece are the knights. The others dressed in plain tunics and caps are the common soldiers. The cross already appears on William's standard.

ET HIC: TRANSIERVNT: FLVMEN : COSNONIS :

\section{And here they crossed the River Couesnon.}

The River Couesnon, the boundary between Normandy and Brittany, empties into the bay of Cancale immediately opposite Mont Saint-Michel. It is famous for its treacherous and shifting sands, and the more wary of William's soldiers dismount and cross on foot, carrying their arms above their heads.

\section{HIC: HAROLD : DVX: TRAHEBAT : EOS :- DE ARENA}

Here Harold the Earl dragged them out of the Quicksand.

Harold is here shown exerting the strength for which he was famous. He has caught one drowning man up upon his back, and is dragging another forward by the hand. The designer by recording this incident indicates the impression that feats of bodily prowess made upon the minds of people in those days.

\section{ET VENERVNT AD DOL: ET: CONAN :- FVGA VERTIT : \\ And they came to Dol and Conan fled.}

The siege of Dol by Conan would appear to have been unknown to William. His soldiers, galloping up to the walls, are not in 
armor. Nevertheless, Conan's soldiers are represented as fleeing upon their approach. The man escaping from the besieged town by a rope may be a messenger sent to William to acquaint him with the condition of affairs.

\section{REDNES}

\section{Remes.}

Rennes was the capital of Brittany and thither Conan fled to rally his forces. At least, this is the reason commonly assigned for the introduction here of this distant view of the castle.

HIC MILITES WILLELMI: DVCIS: PVGNANT: CONTRA DINANTES : ET: CVNAN : CLAVES PORREXIT:

\section{Here Duke William's soldiers fight against the men of Dinan,} and Conan reached out the keys.

Here we have a spirited illustration of an attack on a fortified town in the middle of the eleventh century. The town is surrounded by the customary fosse and vallum. A gate at the lower end of the bridge guards the approach. A massive keep overlooks the walls. The Norman soldiers in full armor rush to the attack. A party comes out to repulse them. Taking advantage of this diversion, two knights unobserved set fire to the palisades. This probably puts an end to further resistance, and the final surrender is accomplished by the beleaguered chief handing the keys over the walls on the point of his lance, to William, who receives them in the same manner.

The capture of Dinan is an event recorded only in this tapestry, as, according to Lancelot, no mention of it is made by any of the historians of the time. The designer of the tapestry probably obtained the details which have been preserved to us from the descriptions of those who returned to Bayeux after the expedition.

\section{HIC: WILLELM : DEDIT: HAROLDO : ARMA Here William gave arms to Harold.}

By this act William gives Harold a crowning proof of his favor and esteem. The ceremony is significant of knighthood. Both figures are armed cap à pie, and Harold holds in his hand the banner which by virtue of the dignity now bestowed upon him he is entitled to bear. 
The defensive armor of the Normans and Saxons at the time of the Conquest was very much alike. It was of two kinds, formed respectively of leather and of steel. The former consisted of a tunic made of numerous overlapping flaps. The archers wore leather jerkins, with a cap to guard the head. The steel armor was formed of flat rings sewed on a foundation of leather or cloth. It was either a cuirass or tunic, or haubergeon-like that shown here, which forms at once breeches, jacket, and hood. The head was protected by a conical steel helmet with a projecting flap or nose-guard. Besides the harness, the knights carried a kite-shaped shield. In one or two places in the tapestry Harold's companions are represented as carrying a round shield with a projecting boss. This Mr. Fowke regards as the truly English type. For weapons, the Normans carried a bow and arrows, a lance, sword, and mace. The English carried the javelin and the sword, and were beginning to use the bow and arrow as weapons, but their distinctive arm was the axe, sometimes one-handed, but generally the ponderous twohanded weapon.

\section{HIC WILLELM VENIT: BAGIAS VBI HAROLD: SACRAMENTVM : FECIT $:$ WILLELMO DVCI : \\ Here William came to Bayeux, where Harold made an oath to Duke William.}

Historians differ as to the place where Harold took his celebrated oath. Wace, in his Roman de Rou, agrees with the tapestry in making Bayeux the locality. Opinions differ, also, as to the nature of the oath itself. The story commonly accepted is that Harold swore to marry William's daughter, to give his own sister in marriage to a Norman noble, and to deliver up England to William upon the death of Eadward. Tradition adds that having assembled his parliament William caused a chest to be filled with the holiest relics that he could find, and covered it with a pall. Harold took the oath with his hand upon the pall, after which, William, to make the oath more binding, uncovered the chest and showed Harold on what holy relics he had sworn. The tapestry shows us the party approaching Bayeux by a bridge of the ordinary construction. The dome of the cathedral rises above the walls. The ceremony of administering the oath takes place outof-doors. William is seated in state upon his throne. Harold stands bareheaded between a reliquary and an altar bearing the 
host, with his hand resting upon one and his fingers touching the other, while he registers his vow.

This scene was borrowed from the tapestry to be sculptured on one of the columns in the nave of the cathedral.

\section{HIC HAROLD : DVX : REVERSVS: EST AD ANGLICAM : TERRAM : \\ Here Harold the Earl returned to England.}

When William had extorted from the Saxon an oath of fealty he gave him safe conduct to return to England. Harold is seen crossing the sea in a ship, seemingly manned by Norman sailors. The building on the shore has been conjectured to represent Harold's palace of Bosham. The approach of the ship has been observed. The windows of the house are filled with curious gazers. One figure, that may be Harold's wife Ealdgyth, has come out upon the balcony to signal welcome to the returning voyagers.

\section{ET VENIT: AD : EDWARDV̄ : REGEM : And came to King Eadward.}

On his arrival in England Harold takes horse and sends his squire ahead to Westminster to announce his coming. In his audience with the King the latter is represented as enfeebled by age and sickness, seated on his throne with his sceptre reversed in his hand.

HIC PORTATVR: CORPVS: EADWARDI : REGIS:

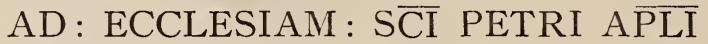

Here King Eadward's body is carried to the church of

St. Peter the Apostle.

Here again the order of time is inverted, the scene of Eadward's obsequies preceding the scene of his sickness and death. The funeral ceremonies are strikingly simple. The body of the King, enclosed in a sack, is laid on a bier borne upon the shoulders of eight noblemen. Crosses are set up at the ends of the bier. Boys ringing bells walk beside the body. Behind follow a group of clergy, surrounding the two chief ministers of the ceremony, who are carrying their office-books.

The procession is moving toward the Church of St. Peter the Apostle (Westminster Abbey). The hand issuing from a cloud 
above the church may represent the divine benediction of the dead King, or it may be an emblem of the peculiarly sacred character of the church edifice. The recent completion of the church is indicated by the workman fixing the weather-cock upon the east end. The new edifice is seen to have consisted of a nave and chancel, the junction occupied by a lofty tower terminating in a crosscrowned dome.

\section{HIC EADIVARDVS: REX IN LECTO : ALLOQVIT: FIDELIS :}

Here King Eadward; in bed, speaks to his Vassals.

The King is dressed in his royal robes and wears his royal crown, a circlet of gold surmounted by fleurs-de-lys. From conteniporary accounts of the death of Eadward, we may discover who the other figures in the scene probably represent. Robert the Staller supports his royal master. Archbishop Stigand and Harold stand beside him. Harold's sister, the Lady Eadgyth, kneels at the feet of her husband.

According to Wace the historian, Harold assembled his friends and brought them into the presence of the dying King, where one of them, speaking for the rest, begged Eadward to name Harold as his successor. The King replied that he had given the realm at his death to the Duke of Normandy. But Harold urged him, whatever he had done before, to consent now that he-Harold-be king. So at last the King said: "Let the English make the Duke or Harold king, as they please ; I consent." Thus the barons had their will.

\section{ET HIC: DEFVNCTVS EST}

And here he is dead.

Two attendants are preparing the body for burial in the presence of an ecclesiastic, probably Stigand the archbishop.

\section{HIC DEDERVNT: HAROLDO : CORO $\cdot \mathrm{NA}$ : REGIS - Here they gave the King's crowen to Harold.}

As soon as Eadward was dead the Witan of England assembled and declared in favor of Harold as his successor. The scene represents two of the assembly notifying Harold of their choicc. They bring with them the crown and the official axe. 
HIC RESIDET: HAROLD REX: ANGLORVM : Here is seated Harold, King of the English.

The coronation of Harold is here represented as having been attended with the usual ecclesiastical rights. Archbishop Stigand, the officiating prelate, stands beside the throne. The scene is an apartment in Westminster, and without the palace the people are applauding the new King.

\section{STIGANT ARCHIEP̄S Archbishop Stigand.}

The inference intended to be drawn from the tapestry is, that Harold was consecrated by Archbishop Stigand; thus invalidating his title to the throne, because the ecclesiastical position of Stigand was very doubtful. The see of Canterbury had been bestowed upon him by the King's writ, but the Pope refused him the pallium. He was afterwards invested by Benedict, the anti-pope, but this only complicated matters. Stigand was finally deposed and degraded from the clerical order.

\section{ISTI MIRANT STELL $\bar{A}$ \\ These men are dismayed at the Star.}

The appearance of this comet is recorded in nearly every chronicle of the day, and it was generally accepted as a presage of the conquest of England. The representation is especially interesting as affording the earliest known illustration of these erratic bodies.

\section{HAROLD \\ Harold.}

Harold is bending forward to listen to a messenger. The messenger brings a sword, and Harold holds a javelin in his hand. This, in connection with the ships in the border, may signify news of William's invasion. Or the group may be taken to show how Harold received the tidings of the appearance of the comet and the interpretations of the omen.

\section{HIC: NAVIS: ANGLICA: VENIT - IN TERRAM WILLELMI : DUCIS}

Here an English ship came into the territory of Duke William.

Of the many Normans whom Eadward had brought into England, some were allowed to remain after Harold's succession to the throne. Some of these, doubtless, sent William the news of Eadward's death and Harold's coronation. 


\section{HIC: WILLELM DVX: IVSSIT NAVES: EDIFICARE:}

\section{Here Duke IVilliam gave orders to build ships.}

William's decision of character is inclicated here. As soon as the messenger has made known to him the state of affairs in England he determines what course he will pursue. We see him ordering a ship-carpenter to set men to work at once building ships. In this scene Bishop Odo, William's half-brother, whom we recognize by his tonsure, appears for the first time. We shall shortly see what an active part he took in the invasion. The architecture of the room in which William is seated is interesting. The roof is in the form of a compressed dome lighted by a lantern in the centre.

\section{HIC TRAHV $\stackrel{\circ}{\mathrm{N} T}$ : NAVES: AD MARE: \\ Here they drag the ships to the sea.}

The work of building the ships went actively forward, and as they were completed the vessels were dragged down to the sea and launched. Had the ships been of large size they could hardly have been moved in this manner.

ISTI PORTANT: ARMAS: AD NAVES: ET HIC TRAHVNT: CARRV·M CVM VINO: ET ARMIS:

These men carry the arms to the ships, and here they drag a cart with wine and arms.

The men are bringing arms and provisions from a store-house to the ships. The great weight of the hauberk is shown by the way in which it is carried. One man has a cask on his shoulder and another a wine-skin bottle. A large cask on a cart is kept in place by a rack of spears and helmets. It has been remarked that the Normans supplied themselves with wine, leaving England to supply them with food.

+ HIC: WILLELM : DVX IN MAGNO: NAVIGIO: MARE TRANSIVIT ET VENIT AD PEVENES $Æ$ :

Here Duke William crossed over the sea in a great ship, and came to Pevensey.

William's departure from S. Valery-sur-Somme on the 27 th September, I066, is witnessed from the shore by a company of his 
knights. All the boats are crowded with soldiers, and many of them carry horses. In the midst of the fleet we recognize the ducal ship, the historic Mora, the gift of William's wife. On the stern is the effigy of their little son Rufus, and at the masthead is the consecrated banner with which Pope Alexander II. sanctioned the expedition. Early the next morning the shores of England were sighted, and by nine o'clock William had landed, unopposed, at Pevensey.

\section{HIC EXEVNT: CABALLI DE NAVIBVS:}

\section{Here the horses go out of the ships.}

Landing horses from ships is always, even now, a matter of some difficulty, and we may conjecture from the event being recorded here, that the disembarkation of the animals after their voyage across the channel occasioned considerable trouble.

\section{ET HIC: MILITES: FESTINAVERVNT: HEST- INGA: VT CIBVM . RAPERENTVR:}

\section{And here the knights pushed on to Hastings to find food.}

The eagerness of the soldiers to forage for breakfast is shown in this scene. As soon as the ships were drawn on shore a party of horsemen set off. We see, too, how successful they were. The English have fled from their homes-square wooden houses, seemingly-leaving sheep, oxen, and pigs behind to be seized. It is interesting to note the use of the lasso by one of the foragers.

\section{HIC : EST : WADARD : \\ Here is Wadard.}

Lancelot, in commenting upon the tapestry, says that it mentions incidents and proper names unrecorded by the chroniclers of the time, from which we must conclude that it has not copied any historian, but is an original work contemporary with the Conquest. This mention of Wadard is a case in point. We know nothing more of him than is shown here, where he appears sharing in the amusement of a footman over the capture of a comical little packhorse. 
HIC: COQVITER: CARO ET HIC: MINISTRAVERIN' MINISTRI :

Here meat is cooked and here the servants serve.

The sequence of events in these scenes is very entertaining. Having foraged successfully, the soldiers give the servants the food to prepare for the meal. Two men suspend a large pot between forked sticks over a fire. Behind them on a shelf are fowl spitted for broiling. A baker is engaged in taking cakes from a stove. Other men are handing the cooked meats in, to be placed on the table or sideboard improvised from the shields of the soldiers. A blast on a horn announces that the meal is prepared.

HIC FECERVN ${ }^{\top}$ : PRANDIVM: ET $\cdot$ HIC $\cdot$ EPISCOPVS : CIB $\bar{V}:$ ET : POT $\bar{V}:$ BENEDICIT :

Here they make a feast, and here the Bishop blesses the food and drink.

In this scene, the feast that we have just seen in preparation is in progress. The table is in the form of a half circle, served from within. On it are fish, viands of different kinds, drinking vessels of several shapes, knives, and other small articles. A kneeling servant is offering a covered porringer to one of the guests. Bishop Odo, seated at William's left hand, is asking a blessing on the repast.

ODO : $\mathrm{EPS}$ :

ROTBERT :

IVILLELM :

Bishop Odo. Robert. William.

A temporary pavilion has been erected for William. Here he holds a council of war with his half-brothers Odo and Count Robert of Mortain. Odo is speaking, and his words are earnestly listened to by the others.

ISTE-IVSSIT: VT FODERETVR: CASTELLVM : AT $\cdot$ HESTENG $^{\mathrm{A}}$

The latter commanded that a rampart should be thrown up at Hastings.

The latter, that is, Robert of Mortain, gives the order to the workmen and superintends the work. Picks, shovels, and spades are used by the laborers. The spades are peculiar as having but one tread for the foot. 


\section{CEASTRA}

\section{The camp.}

An intrenchment and mound are rapidly made, and on the latter a fort is erected. The fort probably represents one of the portable wooden strongholds that the Normans carried with them in war.

\section{HIC: NVNTIATVM EST : WILLELM DE HAROLD : \\ Here tidings of Harold are brought to William.}

An armed knight is giving William news of Harold. Probably he is telling him of the success of the Saxon forces in the North against William's Scandinavian allies, and that the victorious troops are now hurrying southward to engage the Normans. William is represented seated and holding the consecrated banner in his hand.

\section{HIC: DOMVS : INCENDITVR :}

\section{Here a house is burnt.}

Harold intrenched his forces on the hill of Senlac on the $13^{\text {th of }}$ October, and is reported to have laid waste the surrounding country in order to starve the invaders into favorable terms. Mr. Fowke, however, points out that the incendiaries, in the scene before us, are plainly Normans, and that the superior style of the house shows that it was a dwelling of a person of note.

HIC : MILITEs : EXIERVNT: DE HESTENGA : ET : VENERVNT AD PRELIVM: CONTRA: HAROLDVM : REGE :

\section{Here the knights left Hastings, and came to give battle to King Harold.}

Before the army starts on its march, William, in a kind of avantscène comes forth fully armed from his quarters at Hastings and mounts his charger. Then traversing a small wood he puts himself at the head of his army. In the passage he has exchanged his sword for a mace. The knight who follows him is armed in the same manner. They are accompanied by two standard-bearers-one carrying the consecrated banner, and the other carrying a banner that has been thought to represent the celebrated Black Raven of the Danes. 
HIC: WILLELM : DVX INTERROGAT: VITAL: SI VIDISSET HAROLDI EXERCIT $\bar{V}$ :

Here Duke IVilliam asks Vital if he had scen Harold's army.

A mounted warrior is returning at full speed from a reconnoissance. The Duke questions him and he replies, as his gesture indicates, that his soldiers, from their hiding behind the brow of a small wooded eminence, have seen the opposing army. It is interesting to notice how the artist, ignorant of laws of perspective, has here indicated the topography of the country.

\section{ISTE NVNTIAT: HAROLDVM REGE DE EXERCITV WILELMI DUCIS}

One informs King Harold concerning the army of Duke William.

Harold on his side receives reports of the position of the enemy. One of his spies is shown reconnoitering the enemy from an eminence, and immediately afterwards delivering his report to the King. The historians tell us that Harold took up his position on the Hill of Senlac and surrounded it, on the accessible sides with a triple palisade, and on the south with a ditch.

HIC IVILLELM : DVX ALLOQVITVR: SVIS: MILITIBVS: VT P PREPARAREN SE: VIRILITER ET SAPIENTER: AD PRELIVM : CONRA: ANGLORVM EXERCITV :

Here Duke William exhorts his soldicrs to prepare themselves manfully and discreetly for the battle against the army of the English.

The two armies are face to face. The Norman soldiers are so eager for the conflict that they hasten away almost before William's exhortations are concluded. The cavalry enter the fight preceded by the Norman archers. The battle is opened with a flight of arrows. The Norman knights rush forward to the charge and are met by the solid phalanx of the English, standing shoulder to shoulder, and forming with their interlocked shields the famous shield-wall which even the cavalry could not break through. Harold is seen standing, wielding his terrible two-handed axe, and surrounded by his standard-bearer and his four brothers. The borders of the tapestry here begin to be taken up with incidents of the fight. 


\section{HIC CECIDERVNT LEWINE ET: GÝRD :} FRATRES: HAROLDI REGIS:

Here fell Leofwine and Gyrth, the brothers of King Harold.

William, Odo, and Robert press forward to where Harold is fighting surrounded by his brothers. Two of the latter are armed with the round-bossed shields peculiar to the English. In the encounter that follows, Leofwine and Gyrth are killed, and shortly afterwards we are shown Harold wielding his great axe singly and alone.

\section{HIC CECIDERVN SIMVL: ANGLI ET FRANCI :} IN PRELIO :

Here English and French fell at the same time in the battle.

This is the climax of the fight. The first advance of the Norman attack on the Hill is driven back to a deep ravine covered with brushwood, where horses and riders were tumbled into the chasm, and mingled in inextricable confusion. In a subsequent attack the English line is broken and the Normans gain a position on the Hill.

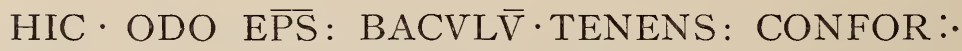
TAT PVEROS

Here Bishop Odo, holding a club, rallies the young troops.

We know that at the battle of Hastings several churchmen were engaged fighting in the Norman and the English ranks. Here Bishop Odo is shown clad in armor and armed with a mace, engaged in rallying a body of the "young troops" that had been seized with a panic.

\section{HIC EST: WILEL DVX \\ Here is Duke William.}

According to the historians a report was spread at one stage of the fight, that William had been killed, and the Normans began to retreat. William heard the report and raising the nasal of his helmet, rushed into the midst of his soldiers exclaiming, "I am here" -or, perhaps as Mr. Fowke suggests, the words of the inscription may have been the identical exclamation that he used. 


\section{5 \\ E...TIVS \\ Eustace.}

At the time of the above incident Eustace, Count of Boulogne, was at William's side urging him to retreat. The tapestry shows Odo and William occupying positions at each end of a body of soldiers, the greater part of whom have regained their former ardor.

\section{HIC: FRANCI PVGNAN ET CECIDERVNT QVI ERANT : CVII HAROLDO :}

\section{Here the French fight and those who were with Harold fell.}

No defense was now left to the.English except their shield-wall. It was at this stage of the fight that William gave the order that won the day-"Shoot upwards, Norman archers." The border illustrates the act. The arrows falling from above demoralized the English, and their defense was broken.

\section{HIC HAROLD $:$ REX $:$ INTERFECTVS: EST \\ Here King Harold was slain.}

The chroniclers tell us that Harold while wielding his axe was pierced in the eye by an arrow. Dropping his axe, he strove to pluck the arrow from his eye, the shaft broke in his grasp, and he fell to the ground in mortal anguish. The scene in the tapestry is very similar to this description. He falls at the foot of the standard, where his body is mutilated by the enemy. The border shows marauders robbing the bodies of the slain, and the piling up of the arms on the field.

\section{ET FVGA: VERTERVN ANGLI And the English fled.}

After the strain of the conflict, there is something almost amusing in this scene, where the flight of the English is depicted. Here the tapestry in its present condition ends, nor does it seem ever to have been of much greater length. Lancelot, writing in $173^{\circ}$, says, that in his time the last scene of the tapestry was considerably damaged. In Mr. Stothard's careful drawing, made in I8I6, it is readily seen that all the missing parts have been destroyed by time. By the time the last restoration was made, in 1842 , all the letters 
of the final inscription had disappeared. We can, perhaps, supply some of the missing details by consulting Baudri's poem addressed to Adela, a daughter of the Conqueror. Baudri lived in the latter part of the eleventh century. The poem recounts how William on the morning after the battle orders his standard to be brought to him. He addresses his soldiers and says to them: "Let us march on the town. Rewards are for to-morrow." We are not told the name of the town. The army advances and the terrified inhabitants sue for peace. Then only is it that the people and the nobles proclaim him King. 
SMITHSONIAN INSTITUTION LIBRARIES

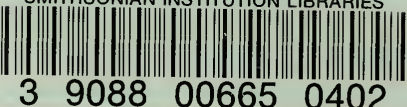

30088006650402 